\title{
Investigations of the Toxic Effect of Silver Nanoparticles on Mammalian Cell Lines
}

\author{
F. Sambale, ${ }^{1}$ S. Wagner, ${ }^{1}$ F. Stahl, ${ }^{1}$ R. R. Khaydarov, ${ }^{2}$ T. Scheper, ${ }^{1}$ and D. Bahnemann ${ }^{1}$ \\ ${ }^{1}$ Institute of Technical Chemistry, Leibniz University Hannover, Callinstraße 5, 30167 Hannover, Germany \\ ${ }^{2}$ Institute of Nuclear Physics, Tashkent, Uzbekistan
}

Correspondence should be addressed to F. Stahl; stahl@iftc.uni-hannover.de

Received 10 December 2014; Revised 9 February 2015; Accepted 9 February 2015

Academic Editor: William W. Yu

Copyright (c) 2015 F. Sambale et al. This is an open access article distributed under the Creative Commons Attribution License, which permits unrestricted use, distribution, and reproduction in any medium, provided the original work is properly cited.

Silver nanoparticles are widely used for many applications. In this study silver nanoparticles have been tested for their toxic effect on fibroblasts (NIH-3T3), on a human lung adenocarcinoma epithelial cell line (A-549), on PC-12-cells, a rat adrenal pheochromocytoma cell line, and on HEP-G2-cells, a human hepatocellular carcinoma cell line. The viability of the cells cultivated with different concentrations of silver was determined by the MTT assay, a photometric method to determine cell metabolism. Dose-response curves were extrapolated and $\mathrm{IC}_{50}$, total lethal concentration (TLC), and no observable adverse effect concentration (NOAEC) values were calculated for each cell line. As another approach, ECIS (electric-cell-substrate-impedance-sensing) an automated method to monitor cellular behavior in real-time was applied to observe cells cultivated with silver nanoparticles. To identify the type of cell death the membrane integrity was analyzed by measurements of the lactate dehydrogenase releases and by determination of the caspase $3 / 7$ activity. To ensure that the cytotoxic effect of silver nanoparticles is not traced back to the presence of $\mathrm{Ag}^{+}$ions in the suspension, an $\mathrm{Ag}^{+}$salt $\left(\mathrm{AgNO}_{3}\right)$ has been examined at the same concentration of $\mathrm{Ag}^{+}$present in the silver nanoparticle suspension that is assuming that the Ag particles are completely available as $\mathrm{Ag}^{+}$ions.

\section{Introduction}

Recently nanotechnology has revolutionized the technological progress and is predicted to be one of the key technologies of the 21st century [1]. Nanoparticles are defined with a particle size between 1 and $100 \mathrm{~nm}$. Compared to their bulk counterparts, nanoparticles exhibit different physical and chemical properties. Many properties that are found to change in the nanoscale, for example, physical characteristics, surface area, magnetic, mechanical, optical as well as chemical properties such as reactivity, thermal properties, and so forth. Because of their new properties many of these newly developed nanomaterials are already used in different industries. Typical application fields are, for example, optics, photocatalysis, automotive industry, water and air treatment, fabrics, cosmetics, and health products [1].

Silver has been known for its antibacterial effect for a long time [2]. In ancient Greece, Rome, and Macedonia, silver was used to control infections. Nowadays, silver is used for many bactericidal applications, for example, wound healing [3], water treatment [4], and flower preservation
[5]. Other application fields of silver nanoparticles include catalysis [6], optics [7, 8], electronics [9], and various other areas of science and technology. Currently the most effective application for silver nanoparticles appears to be their usage as antibacterial/antifungal agent $[10,11]$. The manufacturing of bactericidal cotton fibers containing silver nanoparticles for textile industry $[12,13]$ is of great interest, because ordinary cotton fabrics provide an excellent environment for microorganisms [14]. Further applications for silver nanoparticles are paints; for example, nanosilver-based paint should prevent the growth of algae on outside walls [15].

However, at present concerns have been raised concerting the environmental impact of nanoparticles and the possible human exposure. Nanomaterial risk assessment is mainly influenced by the mobility of nanoparticles [1]. In addition, due to the large surface area of nanoparticles pollutants can be adsorbed to nanoparticles. During nanomaterials development accumulation of nanoparticles in the ground water or in the air can occur [1]. As nanoparticles such as silver nanoparticles can be absorbed by plants or other living 
organisms, the particles can reach the food chain [1]. There are a lot of publications reporting the results of investigations of the antibacterial effect of silver nanoparticles. Sotiriou and Pratsinis examined the antibactericidal activity of silver ions and nanosilver particles and reported that the bactericidal activity against gram negative Escherichia coli bacteria is dominated by $\mathrm{Ag}^{+}$ions and not by the silver nanoparticles themselves [16]. Fabrega et al. investigated the effect of colloidal Ag nanoparticles at different $\mathrm{pH}$ values in the presence of Suwannee River humic acids (SRHA) against Pseudomonas fluorescens SBW25 and observed a toxic effect at a concentration of $2000 \mathrm{ppm}$ without SRHA at pH 9 [17]. The effect of silver nanoparticles on aquatic organisms has also been investigated by different research groups [18, 19]. Until ten years ago it was assumed that silver is nontoxic to mammalian cells, except for argyria, a blue coloration of the skin, caused by colloidal silver [20].

The main nanoparticle uptake possibilities into the human body were via the skin, via the respiratory tract, or via the gastrointestinal tract [1]. Thereby, nanoparticle size, shape, and surface modification play an important role in the distribution in the organism. Nanoparticles absorbed via the respiratory tract can reach the lymph stream and the blood circulation [21]. Some studies showed that nanoparticles are able to pass through the blood-brain-barrier [22] and through cell membranes $[23,24]$ and can thus deposit in organs and interact with biological systems.

It has been shown that silver nanoparticles can induce a toxic response of different mammalian cell lines [25-29]. Hence silver nanoparticle exposure resulted in a decreased viability or the release of lactate dehydrogenase in rat liver cells [28], in mouse germline stem cells [27], in human fibroblasts [30], and in rat adrenal cells [31]. Chairuangkitti et al. investigated in vitro toxic effects of silver nanoparticles on human lung carcinoma (A-549) cells and reported a clear relationship to the generation of reactive oxygen species [25]. Kawata et al. investigated the toxic effect of silver nanoparticles in comparison to silver ions and polystyrene nanoparticles which are known as nontoxic nanomaterials to HEP-G2 cells. They contributed the toxic effect to both, the nanosize of these particles as well as the ionic form $\mathrm{Ag}^{+}$[32]. AshaRani et al. investigated the cytotoxic and genotoxic effect of silver nanoparticles on human cells. Their results indicated mitochondrial dysfunction as well as induction of reactive oxygen species (ROS) by Ag-nanoparticles which result in DNA damage and chromosomal aberrations [33]. The induced toxic effects of silver nanoparticles can be divided into ROS-dependent and ROS-independent pathways [25].

Because silver nanoparticles are used in many application fields and previous studies showed the possible hazardous effects of these materials it is important to investigate the toxic action more intensely. Therefore, we have investigated the toxic effect of silver nanoparticles and silver ions on four commonly used cell lines, concentrating on the possible exposure options to the organism. The viability of the cells cultivated in the presence of different concentrations of Ag nanoparticles and $\mathrm{Ag}^{+}$ions was measured employing the MTT assay, a well-established photometric method to determine the cell metabolism. Dose-response curves were extrapolated from these data and Total Lethal Concentration (TLC), No Adverse Effect Concentration (NOAEC), and $\mathrm{IC}_{50}$-values were calculated. Electric-Cell-Substrate-Impedance-Sensing (ECIS), an automated method to monitor cell behavior in real-time, was also carried out. To investigate the cell death the caspase $3 / 7$ activity assay was performed.

\section{Materials and Methods}

2.1. Silver Nanoparticles and Silver Ions. The silver nanoparticles used for the cytotoxic tests were synthesized by the Institute of Nuclear Physics, in Tashkent, Uzbekistan. They were liberated from pure silver electrodes via $12 \mathrm{~V}$ batteryoperated constant current generators. The apparatus used for silver ion generation has been described previously [34]. The water-based colloidal silver solution was obtained by a recently reported three-stage process based on the electroreduction of silver ions in water [35]. The concentration of silver nanoparticles and ions in solution was determined by neutron activation analysis (NAA) [36]. Samples were irradiated in the nuclear reactor of the Institute of Nuclear Physics (Tashkent, Uzbekistan). The product of nuclear reaction ${ }^{109} \mathrm{Ag}(\mathrm{n}, \gamma){ }^{110 \mathrm{~m}} \mathrm{Ag}$ has the half-life $t_{1 / 2}=253$ days.

Through measurements of the intensity of gamma radiation with an energy of $0.657 \mathrm{MeV}$ and $0.884 \mathrm{MeV}$ emitted by ${ }^{110 \mathrm{~m}} \mathrm{Ag}$. A Ge(Li) detector with a resolution of about $1.9 \mathrm{keV}$ at $1.33 \mathrm{MeV}$ the silver concentration was determined. A 6144channel analyzer was used for recording gamma-ray quanta. The silver nanoparticles used in the study were characterized by Khaydarov et al. and obtained a primary particle size of $7 \pm 3 \mathrm{~nm}$ (TEM) [35]. As reference for the cytotoxic testing a silver ion suspension was used $\left(\mathrm{AgNO}_{3}\right)$ at the same total $\mathrm{Ag}$ concentration.

2.2. Dynamic Light Scattering Measurements. To measure the hydrodynamic diameter and the distribution of the silver nanoparticles in water, dynamic light scattering (DLS) measurements were performed. Suspensions $(1 \mathrm{~mL})$ with a concentration of $10 \mathrm{ppm}$ in water were prepared and then measured with a Malvern Zetasizer Nano-ZS (Malvern Instruments, UK). Each measurement was repeated three times to enable the calculation of a standard deviation.

2.3. Cell Culture. Four different cell lines were cultivated: HEP-G2 cells, NIH-3T3 cells, PC-12 cells, and A-549 cells. HEP-G2 cells are human hepatocellular carcinoma cells (DMSZ number: ACC 180), NIH-3T3 cells are mouse fibroblasts (DMSZ number: ACC 59), PC-12 cells are rat adrenal pheochromocytoma cells (DSMZ number: ACC 159), and A-549 cells are human lung carcinoma cells (DSMZ number: ACC 107). All cell lines were cultivated in Dulbecco's Modified Eagle's medium (DMEM) (D7777 Sigma-Aldrich, Steinheim, Germany) supplemented with the respective serum (Table 1) and 1\% antibiotics (penicillin/100 U/mL and streptomycin $/ 100 \mu \mathrm{g} / \mathrm{mL}$ ) in a humidified environment at $37^{\circ} \mathrm{C} / 5 \% \mathrm{CO}_{2}$. After three to four days the cells had grown to approximately $70 \%$ confluence. Afterwards, they were detached with trypsin and cultured in a new cell culture flask. 
TABLE 1: DMEM, additives, and cell number per well used for the experiments (fetal calf serum (FCS), horse serum (HOS), and newborn calf serum (NCS).

\begin{tabular}{lccc}
\hline Cell line & DMEM additives & Doubling time & $\begin{array}{c}\text { Cell number per } \\
\text { well }\end{array}$ \\
\hline A-549 & $10 \%$ FCS & $40 \mathrm{~h}$ & 8.000 \\
NIH-3T3 & $10 \%$ FCS & $20 \mathrm{~h}$ & 6.000 \\
PC-12 & $10 \%$ HOS, 5\% NCS, & & 10.000 \\
HEP-G2 & $1 \%$ sodium pyruvate, & $50-60 \mathrm{~h}$ & 10.000 \\
\hline
\end{tabular}

2.4. Cultivation with Nanoparticle Addition. Depending on the doubling times, the cells were seeded a defined number of cells (see Table 1) in a 96-well plate and were incubated for three days. At day four the medium of each well was removed and $200 \mu \mathrm{L}$ of the different nanoparticle suspensions in varying concentrations in the cell culture medium was added to the wells. The cells were cultivated for three more days after which the viability of the cells was determined by the (3-(4,5-dimethylthiazol-2-yl)-2,5-diphenyl-tetrazoliumbromid)-assay. Moreover the caspase 3/7 activity was measured with the Apo-ONE Homogeneous Caspase-3/7 Assay (Promega, USA) or the lactate dehydrogenase release was determined with the CytoTox-ONETM Homogeneous Membrane Integrity Assay (Promega, USA).

\subsection{Cytotoxicity Test Methods}

2.5.1. MTT-Assay. The viability of the cells was analyzed by the MTT assay (Sigma-Aldrich, Steinheim, Germany). This assay is based on the reaction of the tetrazonium ring by mitochondrial dehydrogenase enzymes and leads to an insoluble blue reaction product [37]. Firstly, the medium was removed from each well. Secondly, $100 \mu \mathrm{L}$ of fresh medium and $10 \mu \mathrm{L}$ of MTT solution ( $5 \mathrm{mg} / \mathrm{mL}$ PBS, sterile) were added to each well and incubated for $4 \mathrm{~h}$ at $37^{\circ} \mathrm{C} / 5 \% \mathrm{CO}_{2}$. After incubation of the dye $100 \mu \mathrm{L}$ of $10 \%$ SDS in $0.01 \mathrm{M} \mathrm{HCl}$ were added and the plates were further incubated for $24 \mathrm{~h}$. The determination of the transmission signals at $570 / 630 \mathrm{~nm}$ was performed using a microplate reader (Bio-Rad, Munich, Germany). Each measurement was repeated three times independently in quintuple to calculate the standard error. Statistical analysis was performed using the Student's $t$-test.

2.5.2. Electric-Cell-Substrate-Impedance-Sensing. ECIS is an automated method to monitor cellular behavior. Cells are grown on electrodes covered with a gold film and an alternating current (AC) signal is applied. As cells attach and spread upon these electrodes, their insulating membranes block and constrain the current flow resulting in measured variations in the electrode impedance. Any changes in the environment that result in morphological changes of the cells alter the current paths and can be readily detected by the ECIS model 1600R (Applied BioPhysics, USA). To implement this experiment, one 8W1E (8 wells, 1 electrode) ECIS slide was incubated for about $24 \mathrm{~h}$ with cell culture medium, with each well of the slide being filled with $400 \mu \mathrm{L}$ of medium.
Afterwards, the medium was removed and 125,000 A-549 cells in $400 \mu \mathrm{L}$ were seeded per well and two electrodes remained cell-free as reference. When the impedance signal was stable, the cells had grown to confluence, the medium was removed, and $400 \mu \mathrm{L}$ of the silver nanoparticle suspension in the culture medium at a concentration of $10 \mathrm{ppm}$ was added to the wells. For each analysis, two wells were filled with the same suspension and three wells were filled with cell culture medium without nanoparticles as a reference. The impedance signal is monitored during the entire time of the measurement which is terminated when the signals do not change anymore.

2.6. Dose-Response-Curves. From the results obtained from the MTT assay, dose-response-curves were plotted for the determination of the "No Observable Adverse Effect Concentration" (NOAEC), the Inhibitory Concentration $\left(\mathrm{IC}_{50}\right)$, and the Total Lethal Concentration (TLC) values. For this the normalized cell viability (viability of cells in normal culture medium $=1$ ) was plotted as a function of the logarithm of the particle or rather the ion concentration in $\mathrm{ppm}$. The theoretical dose-response curves were extrapolated using the following equation:

$$
y=1-\frac{1}{1-e^{a(b-x)}},
$$

with $a=$ curve slope, $b=\mathrm{IC}_{50}$ value [ppm], and $x$ being the absorbance values expressed as percentage cell viability.

NOAEC values were determined with $y$ being $95 \%$ of the maximum response on the normalized cell viability employing the following equation:

$$
\mathrm{NOAEC}=b-\frac{\ln (19)}{a} .
$$

TLC values were determined with $y$ being $5 \%$ of the maximum response on the normalized cell viability with the following equation:

$$
\mathrm{TLC}=b-\frac{\ln (1 / 19)}{a} .
$$

2.7. Caspase 3/7 Activity. The cells were cultivated in 96well plates. The caspase $3 / 7$ activity was measured with the Apo-ONE Homogeneous Caspase 3/7 Assay (Promega, USA). To perform this test $100 \mu \mathrm{L}$ of the Apo-ONE Caspase 
TABLE 2: NOAEC-, IC $_{50^{-}}$, and TLC-values for A-549, NIH-3T3, HEP-G2, and PC-12 cells cultivated with silver nanoparticles and silver ions, respectively.

\begin{tabular}{|c|c|c|c|c|c|c|}
\hline & \multicolumn{3}{|c|}{ Silver nanoparticles [ppm] } & \multicolumn{3}{|c|}{ Silver ions [ppm] } \\
\hline & NOAEC & $\mathrm{IC}_{50}$ & TLC & NOAEC & $\mathrm{IC}_{50}$ & TLC \\
\hline A-549 & 6 & 10 & 14 & 19 & 72 & 144 \\
\hline NIH-3T3 & 3 & 4 & 5 & 59 & 72 & 86 \\
\hline HEP-G2 & 4 & 6 & 9 & 94 & 97 & 99 \\
\hline PC-12 & 3 & 4 & 5 & 24 & 25 & 26 \\
\hline
\end{tabular}

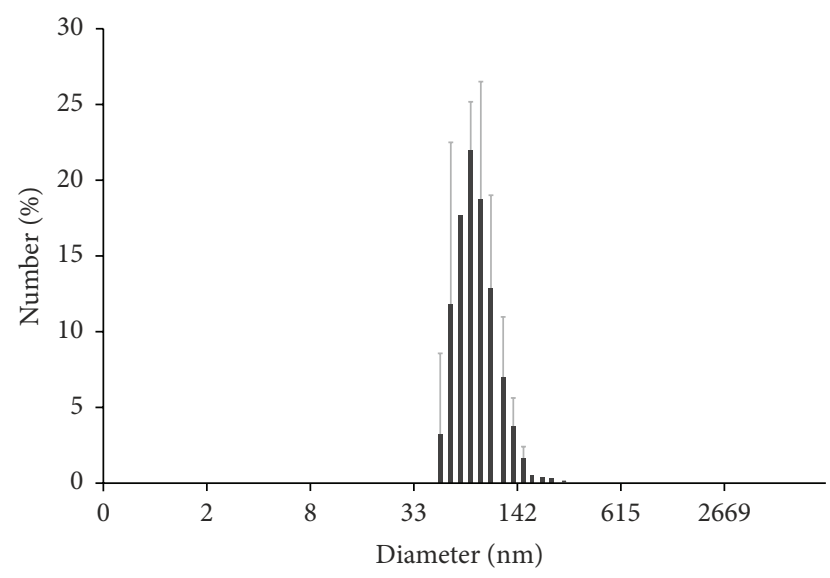

FIGURE 1: DLS measurements of silver nanoparticles at a concentration of $10 \mathrm{ppm}$ in water.

3/7 Reagent was added to each well of the 96-well plate. The plate was shaken for 1 minute at $400 \mathrm{rpm}$ and was then incubated at $22^{\circ} \mathrm{C}$. Every 10 minutes the fluorescence with an excitation wavelength of $485 \mathrm{~nm}$ and an emission wavelength of $538 \mathrm{~nm}$ was measured with the Fluoroskan Ascent (Thermo Electron Corporation). Three independent experiments were performed to calculate the standard error.

2.8. Lactate Dehydrogenase Assay (LDH). The cells were cultivated in 96-well plates. The membrane integrity of the cells was analyzed by the CytoTox-ONETM Homogeneous Membrane Integrity Assay (Promega, USA). To perform the assay $100 \mu \mathrm{L}$ medium from each well was transferred into a new well of a 96-well plate. This plate was incubated for 20 minutes at $22^{\circ} \mathrm{C}$. Afterwards, $100 \mu \mathrm{L}$ of the CytoTox-One reagent was added to each plate. Then the plate was shaken and the fluorescence with an excitation wavelength of $560 \mathrm{~nm}$ and an emission wavelength of $590 \mathrm{~nm}$ was measured with the Fluoroskan Ascent (Thermo Electron Corporation).

\section{Results}

3.1. DLS Measurements. To identify the diameter of the silver nanoparticles used for the cytotoxicity measurements DLS measurements of the particles at Ag concentrations of $10 \mathrm{ppm}$ in water were carried out (Figure 1). In water Ag-NP obtained a hydrodynamic diameter of $70 \pm 5 \mathrm{~nm}$ (mean \pm standard derivation).
3.2. Dose-Response-Curves and Cytotoxicity Data. The first experiment was to measure the viability of the four different cell lines exposed to the silver nanoparticles and to the silver ions at different concentrations via the MTT assay. Figure 2 shows the dose-response curves of the four different cell lines: A-549, NIH-3T3, HEP-G2, and PC-12 cells cultivated in presence of silver nanoparticles and of silver ions, respectively, after $72 \mathrm{~h}$ exposure. The results of the MTT assay were extrapolated using formulas (1) to (3).

In Table 2 the thus calculated $\mathrm{IC}_{50}$ (Inhibitory Concentration), TLC (Total Lethal Concentration), and NOAEC (No Observable Adverse Effect Concentration) values for the different cell lines cultivated with silver nanoparticles and with silver nitrate are shown.

For all cell lines the decrease of the viability is much higher by cultivation in the presence of silver nanoparticles than by cultivation with silver ions (Figure 2). For all cell lines the $\mathrm{IC}_{50}$ values by cultivation in the presence of silver nanoparticles are similar ranging from $4 \mathrm{ppm}$ for the NIH$3 \mathrm{~T} 3$ and PC-12 cells to 10 ppm for the A-549 cells, whereas the slopes of the dose-response curves are varying considerably more, resulting in respective differences in the TLC and NOAEC values. The values calculated for the silver ions differ drastically from those obtained for the silver particles; here the range for the $\mathrm{IC}_{50}$ values is between $25 \mathrm{ppm}$ for the PC-12 cells and $97 \mathrm{ppm}$ for the HEP-G2 cells. The slopes of the curves differ in the same way resulting in a rather narrow toxic dose range between $94 \mathrm{ppm}$ and $99 \mathrm{ppm}$ for the HEP-G2 cells, whereas the toxic dose range for the A-549 cells is quite wide, that is, between $19 \mathrm{ppm}$ and $144 \mathrm{ppm}$.

A-549 cells were chosen for the impedance measurements of cells cultivated in the presence of particles. These experiments were performed to verify the cytotoxicity results obtained from the MTT assay and the dose-response curves.

Figure 3 shows the ECIS of A-549 cells cultivated with silver nanoparticles at the $\mathrm{IC}_{50}$ concentration of $10 \mathrm{ppm}$ in the cell culture medium and the cell growth in normal culture medium as well as the impedance signal of a cellfree-electrode as a reference. The ECIS measurements allow online-monitoring of the nanoparticle effects to the cells. The impedance signal of the electrodes seeded with cells and cultivated with nanoparticles in the culture medium decreases immediately after addition of the particles, indicating a morphology change of the cells on the electrodes or a detachment of cells from the electrode surface, respectively.

The micrographs of the A-549 cells cultivated on the electrodes in normal medium and with $10 \mathrm{ppm}$ silver 


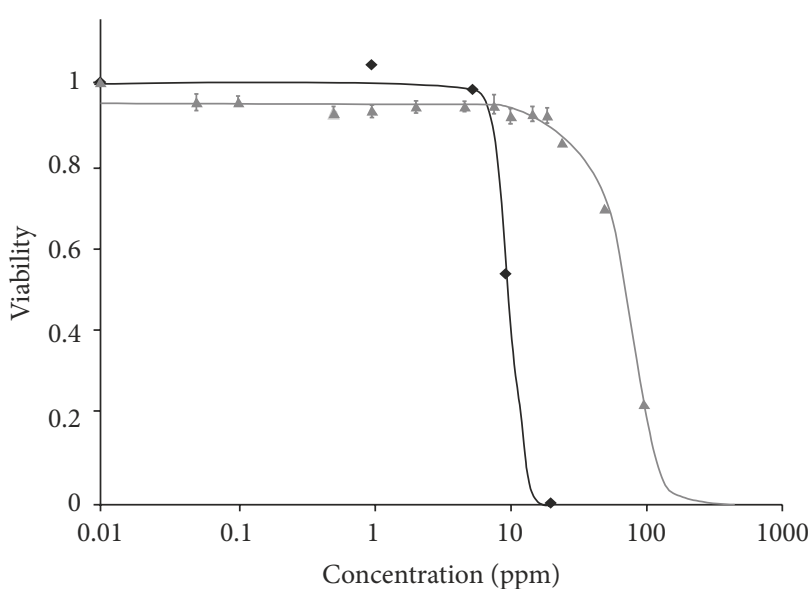

(a)

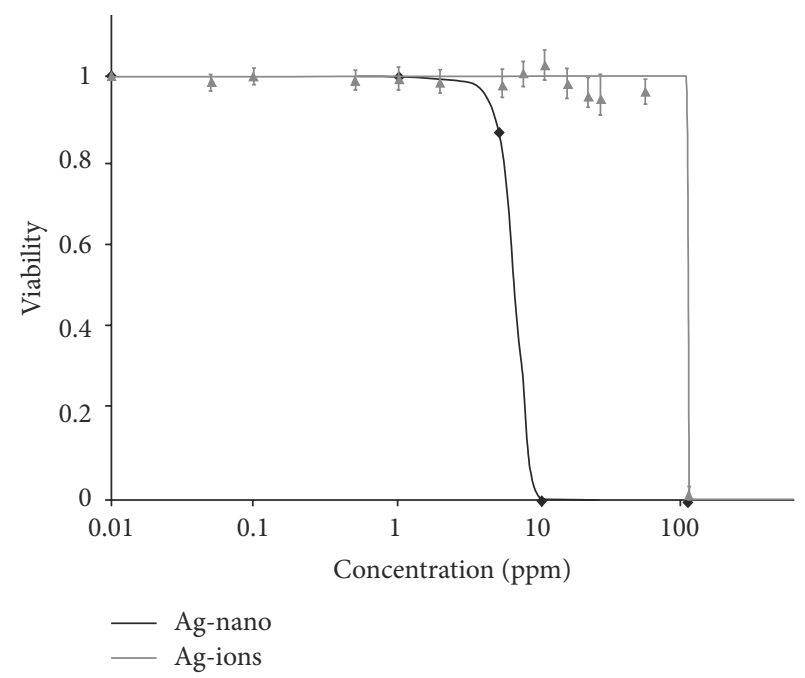

(c)

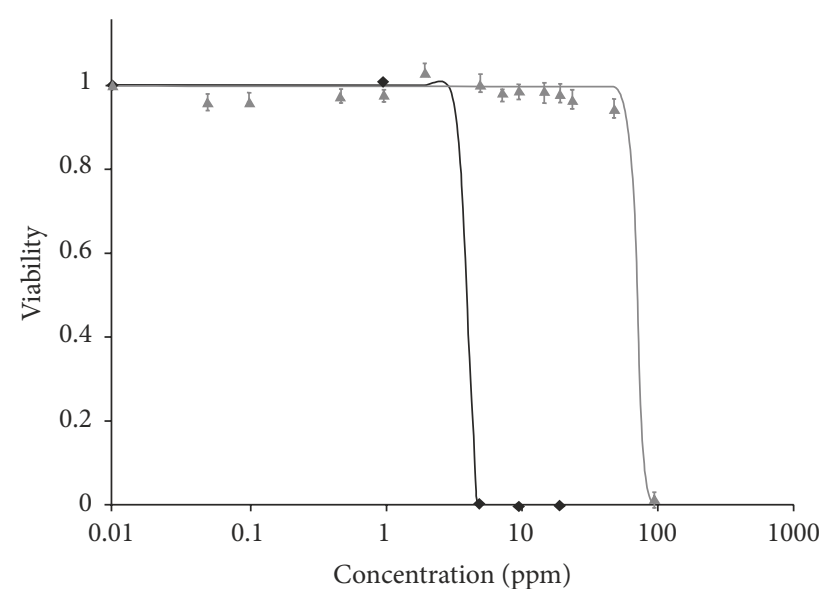

(b)

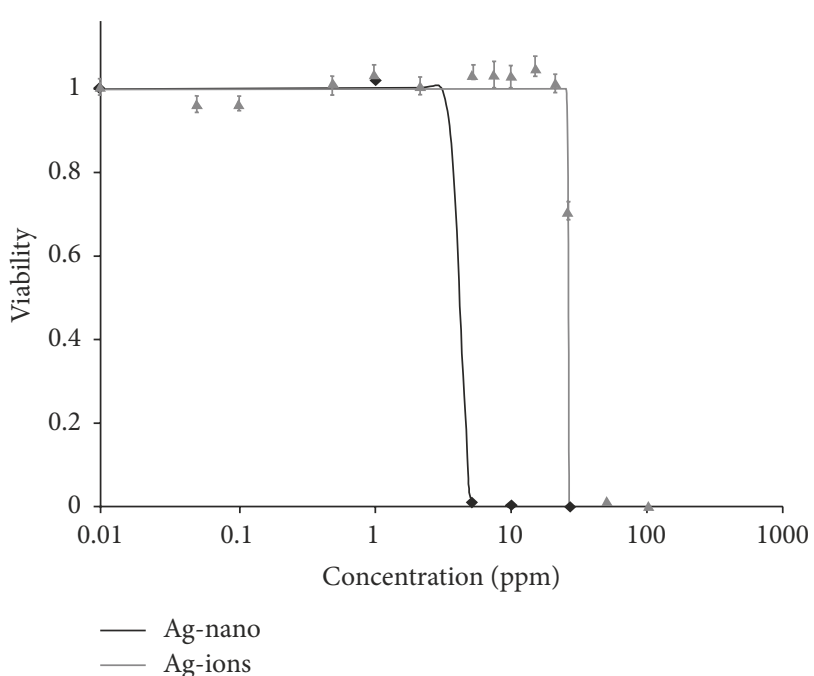

(d)

Figure 2: Viability ( \pm SEM) and extrapolated dose-response curves of A-549 cells (a), NIH-3T3 cells (b), HEP-G2 cells (c), and PC-12 cells (d) cultivated with silver nanoparticles and silver ions, respectively.

nanoparticles in the medium after the impedance measurements, respectively, are shown in Figure 4. The micrographs confirm the decrease of the impedance signal indicating a morphology change of the cells. Moreover, a lower number of cells are found on the ECIS electrode cultivated in the presence of silver nanoparticles in the culture medium as compared with the electrode cultivated in normal culture medium. The treated cells exhibit a more spherical shape in comparison with the untreated cells.

3.3. Determination of Cell Death. To determine cell death, that is, to distinguish between apoptosis and necrosis, LDH measurements and caspase 3/7 activity measurements were performed using A-549 cells. For these experiments concentrations were chosen exhibiting a toxic response in the doseresponse curves of the A-549 cells. The $\mathrm{IC}_{50}$ value of A-549 cells cultivated with silver nanoparticles was determined to be 10 ppm; hence this concentration was used for the determination of the cell death. For the silver ions a concentration of $50 \mathrm{ppm}$ was employed for the determination of the caspase $3 / 7$ activity.

In Figure 5 the caspase 3/7 activity of A-549 cells cultivated with addition of $10 \mathrm{ppm}$ silver nanoparticles in the culture medium and with $50 \mathrm{ppm}$ silver ions as well as the activity of untreated cells in normal culture medium is shown. Cells cultivated with silver nanoparticles show a much higher caspase $3 / 7$ activity than untreated cells. The caspase $3 / 7$ activity of cells cultivated with silver ions at a concentration of $50 \mathrm{ppm}$ is slightly lower than that of untreated cells.

Figure 6 displays the LDH release of the cell culture supernatant of A-549 cells cultivated in normal cell culture medium (untreated cells), with addition of $10 \mathrm{ppm}$ silver nanoparticles and with $10 \mathrm{ppm}$ silver ions. There is no $\mathrm{LDH}$ release in the cell culture supernatant of A-549 cells cultivated with silver nanoparticles at a concentration of $10 \mathrm{ppm}$ evincing that the cell membranes are not destroyed. By cultivation of A-549 cells with $10 \mathrm{ppm}$ of silver ions in the medium there is a $\mathrm{LDH}$ release in the culture supernatant which is, 


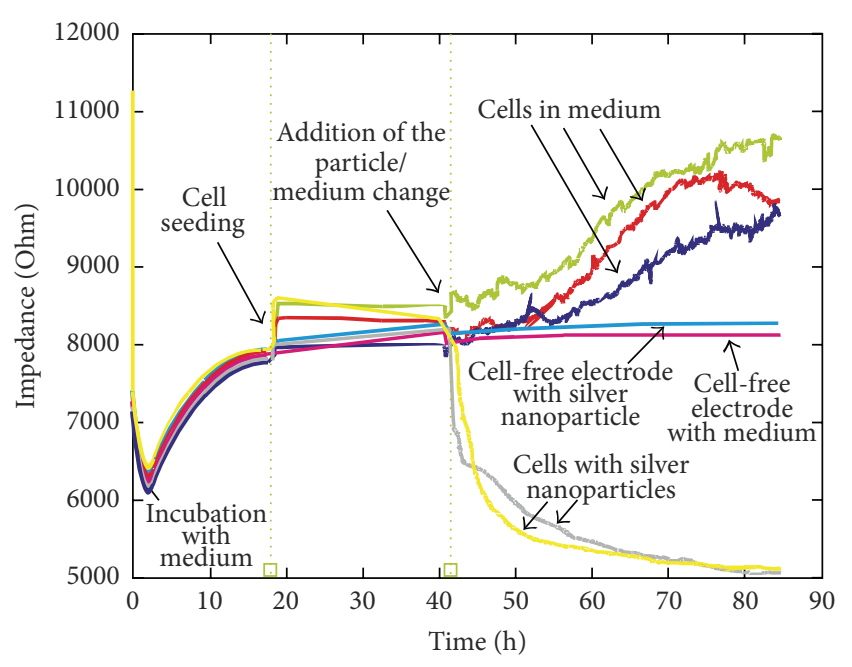

FIGURE 3: Electric-Cell-Substrate-Impedance-Sensing of A-549 cells with addition of silver nanoparticles at a concentration of $10 \mathrm{ppm}$. Cell-free media with and without silver nanoparticles were used as reference and cells in standard medium as control.

however, higher than in the supernatant of untreated cells. This indicates that the membranes are destroyed and the cells die due to necrosis.

\section{Discussion}

DLS measurements of particle suspensions in water (Figure 1) revealed that the hydrodynamic particle diameter is $70 \pm 5 \mathrm{~nm}$. Presumably, the hydrodynamic diameter of Ag nanoparticles in the culture medium could be smaller. Other studies have previously reported and confirmed the nanoparticle stabilization by proteins and sera contained in the medium [38-40]. The results obtained from the viability data of the MTT assay could be good described with the extrapolated dose-response curves (Figure 2).

The calculated $\mathrm{IC}_{50}$, TLC, and NOAEC values are different for each cell line ranging from $3 \mathrm{ppm}$ to $144 \mathrm{ppm}$. The most sensitive cells expressing a toxic response caused by silver nanoparticles are PC-12 and NIH-3T3 cells; here, $\mathrm{IC}_{50}$ values as low as $4 \mathrm{ppm}$ have been determined, whereas the $\mathrm{IC}_{50}$ value for the A-549 cells is about $10 \mathrm{ppm}$. However, in comparison with the sensitivity of the cell lines cultivated in presence of silver ions the variation in the toxic doses is not very high. When cultivating the cells with silver ions $\mathrm{IC}_{50}$ values between $25 \mathrm{ppm}$ for the PC-12 cells and $97 \mathrm{ppm}$ for the HEP-G2 cells have been determined. For each cell line investigated here, the $\mathrm{IC}_{50}$, TLC, and NOAEC values are in the same range. Adding $3 \mathrm{ppm}$ silver nanoparticles to NIH-3T3 cells has no effect; however, upon the addition of 4 ppm almost $50 \%$ of the cells were not viable anymore and once 5 ppm of silver nanoparticles were present in the culture medium only $5 \%$ of the cells were viable, confirming that the range of the toxic doses is very small. The results obtained also show that the toxic effect is not mainly caused by the silver ions but rather by silver nanoparticles for all tested cell lines. This effect has previously been observed in sea urchin Paracentrotus lividus [41].

Braydich-Stolle et al. investigated the toxic effect of $15 \mathrm{~nm}$ sized silver particles and a soluble silver salt (silver carbonate) on C18-4 cells and did not observe any toxic effect for the silver ions in the investigated concentration range [27]. The $\mathrm{EC}_{50}$ values for the particles calculated from the MTS assay are found to be $8.75 \mu \mathrm{g} / \mathrm{mL}$ (8.75 ppm) while for the silver ions they are as high as $408 \mu \mathrm{g} / \mathrm{mL}$ (408 ppm) [27]. In the present study higher toxicity of silver ions $\left(\mathrm{IC}_{50}\right.$ values between 25 ppm and 97 ppm) was observed; however, the $\mathrm{EC}_{50}$ values for the silver particles are found to be in the same range for the cell lines studied here $\left(\mathrm{IC}_{50}\right.$ values between $4 \mathrm{ppm}$ and $10 \mathrm{ppm})$.

Hussain et al. investigated the toxic effect of silver nanoparticles with different sizes on BRL3A rat liver cells [28]. The $\mathrm{EC}_{50}$ value for the silver particles with a diameter of $100 \mathrm{~nm}$ was reported to be $19 \pm 5.2 \mu \mathrm{g} / \mathrm{mL}(19 \pm 5.2 \mathrm{ppm})$ while for particles with a size of $15 \mathrm{~nm}$ an $\mathrm{EC}_{50}$ value of $24 \pm 7.5 \mu \mathrm{g} / \mathrm{mL}(24 \pm 7.5 \mathrm{ppm})$ has been determined [28]. These toxicity values are slightly lower than those found here, but in the same range. On the contrary, Haase et al. reported an $\mathrm{IC}_{50}$ value of $110 \mu \mathrm{g} / \mathrm{mL}(110 \mathrm{ppm})$ for peptide coated silver nanoparticles with a diameter of $20 \mathrm{~nm}$ [38]. Kawata et al. investigated the toxic effect of silver nanoparticles with a size of 7-10 nm of silver carbonate and of polystyrene nanoparticles (as reference) to HEP-G2 cells [32]. They observed a decrease in cell viability by addition of $2 \mathrm{mg} / \mathrm{L}(2 \mathrm{ppm})$ of the silver nanoparticles to the cells. Both the cultivation with polystyrene as a nontoxic nanoparticle reference and that with silver ions in the concentration range between $0.1 \mathrm{mg} / \mathrm{L}$ and $3 \mathrm{mg} / \mathrm{L}$ showed no toxic effect [32]. Our results indicate that there is a toxic effect of silver nanoparticles on HEP-G2 cell when adding concentrations exceeding $4 \mathrm{ppm}$.

The ECIS of A-549 cells cultivated with silver nanoparticles at a concentration of $10 \mathrm{ppm}$ and the reference cell growth in normal medium shown in Figure 3 confirm the toxicity of silver nanoparticles. It is obvious that the impedance signal decreases directly after addition of $10 \mathrm{ppm}$ of silver nanoparticles. That indicates that the toxic effect occurs immediately after the addition of the nanoparticles. In the absence of cells the impedance signal is not influenced by the nanoparticles as shown in Figure 3. The signal of a cell-free electrode with nanoparticles showed the same impedance signal as the cell-free electrode incubated with only medium.

The micrographs of the electrodes taken after the ECIS experiment (Figure 4) confirm these results. The electrode seeded with cells in normal culture medium (Figure 4(a)) showed a confluent cell layer of A-549 cells which in the ECIS measurement was observed as a high impedance signal. The electrode with cells cultivated for $48 \mathrm{~h}$ with silver nanoparticles at a concentration of $10 \mathrm{ppm}$ only showed a few cells on the electrode surface corresponding to a low impedance signal in the measurement. Apparently the dead cells detached from the electrode surface and because of that the impedance signal decreased. The cells which remained attached to the electrode surface exhibited changes in morphology and were found to be smaller than untreated cells which can be regarded as an indicator for apoptosis. Similar 


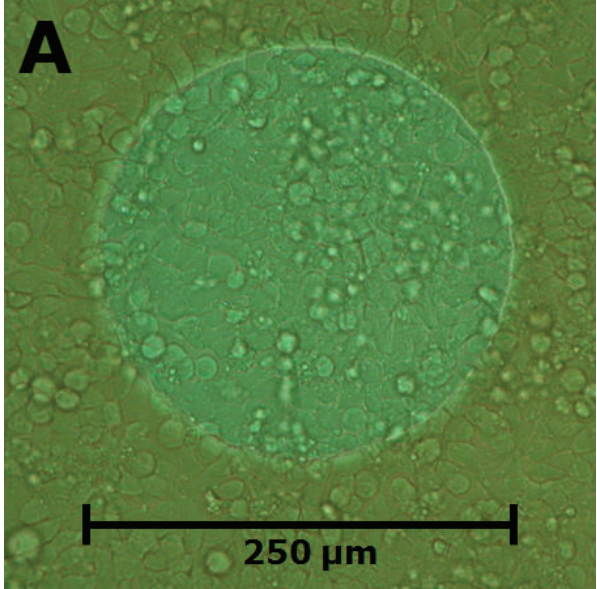

(a)

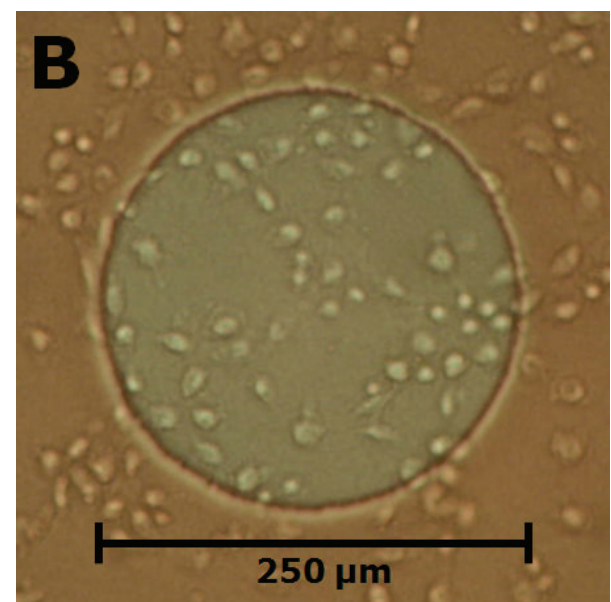

(b)

FIgURE 4: Phase contrast micrographs of A-549 cells on an Electric-Cell-Substrate-Impedance-Sensing electrode (8W1E) in normal culture medium (a) and $48 \mathrm{~h}$ after addition of silver nanoparticles at a concentration of $10 \mathrm{ppm}$ to the culture medium (b).

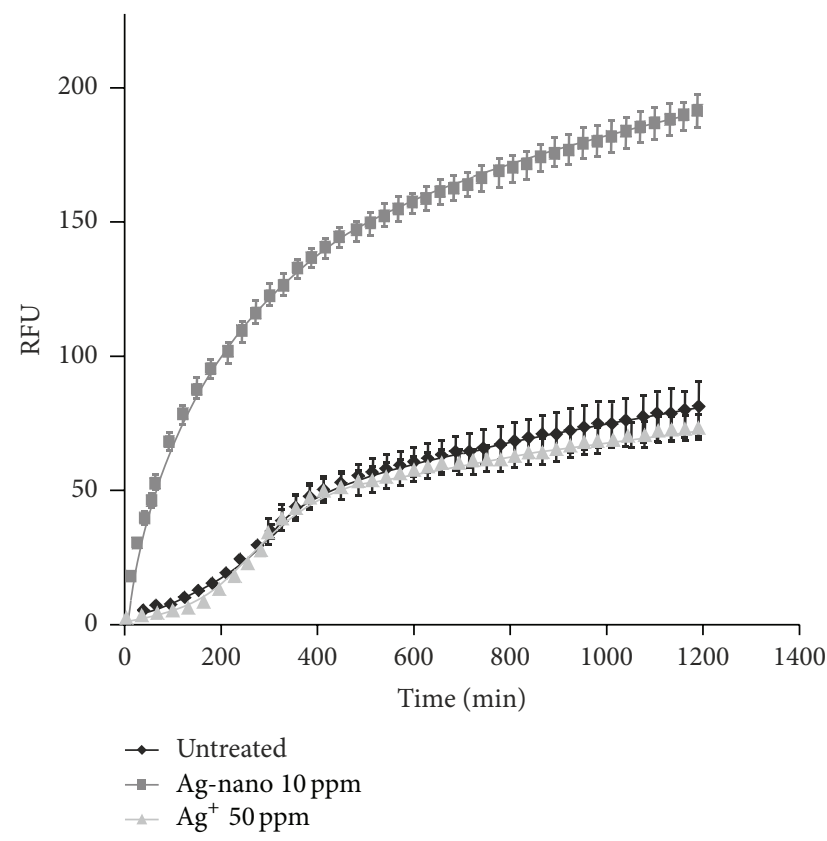

FIGURE 5: Caspase 3/7 activity of A-549 cells cultivated with silver nanoparticles at a concentration of $10 \mathrm{ppm}$, with silver ions at a concentration of $50 \mathrm{ppm}$, and for untreated cells during a cultivation period of $20 \mathrm{~h}$. Data are shown as the mean \pm SEM of three independent experiments.

morphological changes of cells cultivated in the presence of silver nanoparticles at a concentration of $10 \mu \mathrm{g} / \mathrm{mL}$ were observed by Braydich-Stolle and coworkers [27]. The $\mathrm{IC}_{50}$ value of A-549 cells cultivated with silver nanoparticles calculated from the dose-response curves is $10 \mathrm{ppm}$; thus ECIS showed a good correlation with these results.

To determine the kind of cell death $\mathrm{LDH}$ release and caspase 3/7 activity measurements were carried out with A-549 cells cultivated with silver nanoparticles and silver ions. As shown in Figure 6, there was no $\mathrm{LDH}$ release in

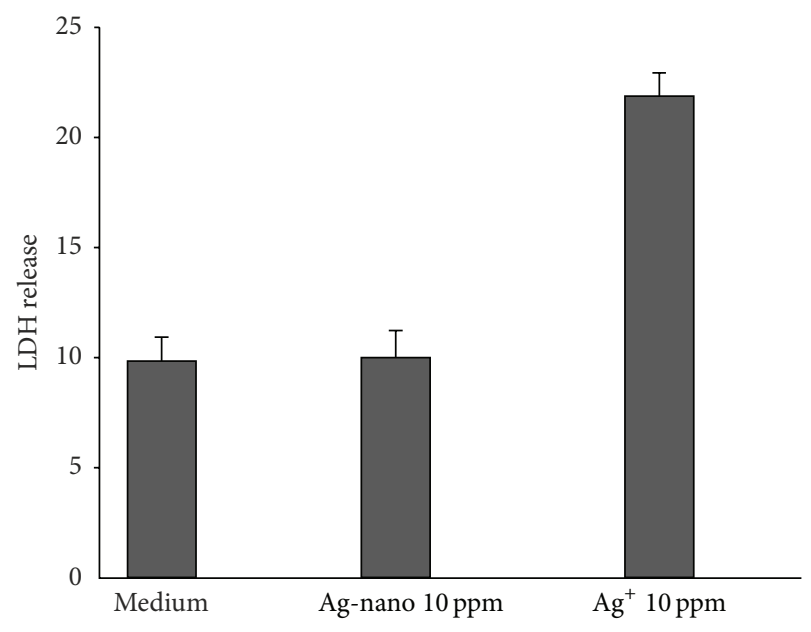

FIGURE 6: LDH release of the cell culture supernatant of A-549 cells cultivated with silver nanoparticles at a concentration of $10 \mathrm{ppm}$ and with silver ions at a concentration of $10 \mathrm{ppm}$ as well as for untreated cells after a cultivation period of $24 \mathrm{~h}$. Data are shown as the mean \pm SEM of five independent experiments.

the cell culture supernatant of the A-549 cells cultivated with silver nanoparticles at a concentration of $10 \mathrm{ppm}$, whereas the overlap of cells cultivated with silver ions showed much more $\mathrm{LDH}$ release which is similar to that observed for untreated cells. This indicates that cell death induced by cultivation with nanoparticles is not related to necrosis, since the cell membranes remain intact. Untreated cell culture also contains cells which due to mechanical interferences are necrotic. Braydich-Stolle et al. also found no significant LDH release in C18-4 cells cultivated with different concentrations of silver nanoparticles in the concentration range between $5 \mu \mathrm{g} / \mathrm{mL}$ and $100 \mu \mathrm{g} / \mathrm{mL}$ (5 and $100 \mathrm{ppm}$ ) [27]. Measurements of the caspase $3 / 7$ activity of A-549 cells cultivated with silver nanoparticles at a concentration of $10 \mathrm{ppm}$ and with silver ions at a concentration of 50 ppm (Figure 5) revealed 
a much higher activity of caspase $3 / 7$ in cells cultivated with the particles as compared to cells cultivated in cell culture medium alone or with addition of $50 \mathrm{ppm}$ silver ions. That indicates that the A-549 cells are undergoing apoptosis by cultivation with silver nanoparticles, whereas the cells cultivated with silver ions do not exhibit apoptosis but rather show necrosis.

The mechanism of cell death is clearly different when cultivation is performed in the presence of nanoparticles or ions, leading to the conclusion that the toxic effect of silver nanoparticles to A-549 cells is indeed not caused by the silver ions. Moreover, these results are supported by the doseresponse curves as well as the calculated $\mathrm{IC}_{50}$ values.

\section{Conclusions}

The toxic effect of silver nanoparticles on four different mammalian cell lines has been investigated studying the mitochondrial activity and employing the Electric-CellSubstrate-Impedance-Sensing (ECIS) method. As reference, $\mathrm{Ag}^{+}$-ions were used at the same concentration as the $\mathrm{Ag}$ atoms present in the particles.

Based upon the results of the MTT assay, dose-response curves were extrapolated and $\mathrm{IC}_{50}$, TLC, and NOAEC values were calculated. The results showed that silver nanoparticles are considerably more toxic than silver ions. Depending on the cell line the respective values were found to be between 5 (PC-12 cells) and 18 (NIH-3T3 cells) times higher.

The results from ECIS measurements indicate that the toxic effect of the silver nanoparticles occurs immediately after addition of the silver nanoparticle suspension. Measurements of LDH release of the cell culture supernatant of cells cultivated with nanoparticles or ions, respectively, showed no release for cells cultivated with the particles but $\mathrm{LDH}$ release for the ions. Cells cultivated with toxic doses of nanoparticles or ions, respectively, showed caspase $3 / 7$ activity for the nanoparticles but no activity for the ions. Clearly, the mechanism of cell death is different when cultivations are carried out with silver particles or with ions. Cells cultivated in the presence of particles apparently suffer apoptosis while cells cultivated with ions die due to necrosis.

\section{Conflict of Interests}

The authors declare that there is no conflict of interests regarding the publication of this paper.

\section{Acknowledgments}

This work was supported by the German Federal Ministry of Education and Research (BMBF Project "HelioClean," Grant no. 03X0069F). For constructive discussions Professor Cornelia Kasper is gratefully acknowledged.

\section{References}

[1] S. Wagner, J. Bloh, C. Kasper, and D. Bahnemann, "Toxicological issues of nanoparticles employed in photocatalysis," Green, vol. 1, no. 2, pp. 171-188, 2011.
[2] H.-J. Jeon, S.-C. Yi, and S.-G. Oh, "Preparation and antibacterial effects of Ag- $\mathrm{SiO}_{2}$ thin films by sol-gel method," Biomaterials, vol. 24, no. 27, pp. 4921-4928, 2003.

[3] C. Rigo, L. Ferroni, I. Tocco et al., "Active silver nanoparticles for wound healing," International Journal of Molecular Sciences, vol. 14, no. 3, pp. 4817-4840, 2013.

[4] D. V. Quang, P. B. Sarawade, S. J. Jeon et al., "Effective water disinfection using silver nanoparticle containing silica beads," Applied Surface Science, vol. 266, pp. 280-287, 2013.

[5] H. J. Klasen, "A historical review of the use of silver in the treatment of burns. II. Renewed interest for silver," Burns, vol. 26, no. 2, pp. 131-138, 2000.

[6] L. N. Lewis, "Chemical catalysis by colloids and clusters," Chemical Reviews, vol. 93, no. 8, pp. 2693-2730, 1993.

[7] J. Luo, J. Yao, Y. Lu, W. Ma, and X. Zhuang, "A silver nanoparticle-modified evanescent field optical fiber sensor for methylene blue detection," Sensors (Switzerland), vol. 13, no. 3, pp. 39863997, 2013.

[8] C. J. Murphy, T. K. Sau, A. M. Gole et al., "Anisotropic metal nanoparticles: synthesis, assembly, and optical applications," Journal of Physical Chemistry B, vol. 109, no. 29, pp. 13857-13870, 2005.

[9] Y. Li, Y. Wu, and B. S. Ong, "Facile synthesis of silver nanoparticles useful for fabrication of high-conductivity elements for printed electronics," Journal of the American Chemical Society, vol. 127, no. 10, pp. 3266-3267, 2005.

[10] S. Prabhu and E. K. Poulose, "Silver nanoparticles: mechanism of antimicrobial action, synthesis, medical applications, and toxicity effects," International Nano Letters, vol. 2, no. 1, article 32, 2012.

[11] C. Buzea, I. I. Pacheco, and K. Robbie, "Nanomaterials and nanoparticles: sources and toxicity," Biointerphases, vol. 2, no. 4, p. MR17, 2007.

[12] H. J. Lee, S. Y. Yeo, and S. H. Jeong, "Antibacterial effect of nanosized silver colloidal solution on textile fabrics," Journal of Materials Science, vol. 38, no. 10, pp. 2199-2204, 2003.

[13] H. J. Lee and S. H. Jeong, "Bacteriostasis and skin innoxiousness of nanosize silver colloids on textile fabrics," Textile Research Journal, vol. 75, no. 7, pp. 551-556, 2005.

[14] C.-Y. Chen and C.-L. Chiang, "Preparation of cotton fibers with antibacterial silver nanoparticles," Materials Letters, vol. 62, no. 21-22, pp. 3607-3609, 2008.

[15] K. Vasilev, J. Cook, and H. J. Griesser, "Antibacterial surfaces for biomedical devices," Expert Review of Medical Devices, vol. 6, no. 5, pp. 553-567, 2009.

[16] G. A. Sotiriou and S. E. Pratsinis, "Antibacterial activity of nanosilver ions and particles," Environmental Science \& Technology, vol. 44, no. 14, pp. 5649-5654, 2010.

[17] J. Fabrega, S. R. Fawcett, J. C. Renshaw, and J. R. Lead, "Silver nanoparticle impact on bacterial growth: effect of $\mathrm{pH}$, concentration, and organic matter," Environmental Science \& Technology, vol. 43, no. 19, pp. 7285-7290, 2009.

[18] E. Navarro, F. Piccapietra, B. Wagner et al., "Toxicity of silver nanoparticles to Chlamydomonas reinhardtii," Environmental Science and Technology, vol. 42, no. 23, pp. 8959-8964, 2008.

[19] C. M. Zhao and W. X. Wang, "Biokinetic uptake and efflux of silver nanoparticles in Daphnia magna," Environmental Science and Technology, vol. 44, no. 19, pp. 7699-7704, 2010.

[20] X. Chen and H. J. Schluesener, "Nanosilver: a nanoproduct in medical application,” Toxicology Letters, vol. 176, no. 1, pp. 1-12, 2008. 
[21] N. Hussain, V. Jaitley, and A. T. Florence, "Recent advances in the understanding of uptake of microparticulates across the gastrointestinal lymphatics," Advanced Drug Delivery Reviews, vol. 50, no. 1-2, pp. 107-142, 2001.

[22] J. S. Kim, "Toxicity and tissue distribution of magnetic nanoparticles in mice," Toxicological Sciences, vol. 89, no. 1, pp. 338-347, 2006.

[23] S. Foley, C. Crowley, M. Smaihi et al., "Cellular localisation of a water-soluble fullerene derivative," Biochemical and Biophysical Research Communications, vol. 294, no. 1, pp. 116-119, 2002.

[24] S. Kashiwada, "Distribution of nanoparticles in the see-through medaka (Oryzias latipes)," Environmental Health Perspectives, vol. 114, no. 11, pp. 1697-1702, 2006.

[25] P. Chairuangkitti, S. Lawanprasert, S. Roytrakul et al., "Silver nanoparticles induce toxicity in A549 cells via ROS-dependent and ROS-independent pathways," Toxicology in Vitro, vol. 27, no. 1, pp. 330-338, 2013.

[26] K. F. Soto, A. Carrasco, T. G. Powell, K. M. Garza, and L. E. Murr, "Comparative in vitro cytotoxicity assessment of some manufacture dnanoparticulate materials characterized by transmissionelectron microscopy," Journal of Nanoparticle Research, vol. 7, no. 2-3, pp. 145-169, 2005.

[27] L. Braydich-Stolle, S. Hussain, J. J. Schlager, and M.-C. Hofmann, "In vitro cytotoxicity of nanoparticles in mammalian germline stem cells," Toxicological Sciences, vol. 88, no. 2, pp. 412-419, 2005.

[28] S. M. Hussain, K. L. Hess, J. M. Gearhart, K. T. Geiss, and J. J. Schlager, "In vitro toxicity of nanoparticles in BRL 3A rat liver cells," Toxicology in Vitro, vol. 19, no. 7, pp. 975-983, 2005.

[29] M. Grodzik and E. Sawosz, "The influence of silver nanoparticles on chicken embryo development and bursa of Fabricius morphology," Journal of Animal and Feed Sciences, vol. 15, pp. 111-114, 2006.

[30] H. C. Wen, Y. N. Lin, S. R. Jian et al., "Observation of growth of human fibroblasts on silver nanoparticles," in Proceedings of the International Conference on Nanoscience and Technology, vol. 61, pp. 445-449, 2007.

[31] S. M. Hussain, A. K. Javorina, A. M. Schrand, H. M. H. M. Duhart, S. F. Ali, and J. J. Schlager, "The interaction of manganese nanoparticles with PC-12 cells induces dopamine depletion," Toxicological Sciences, vol. 92, no. 2, pp. 456-463, 2006.

[32] K. Kawata, M. Osawa, and S. Okabe, "In vitro toxicity of silver nanoparticles at noncytotoxic doses to HepG2 human hepatoma cells," Environmental Science and Technology, vol. 43, no. 15, pp. 6046-6051, 2009.

[33] P. V. AshaRani, G. L. K. Mun, M. P. Hande, and S. Valiyaveettil, "Cytotoxicity and genotoxicity of silver nanoparticles in human cells," ACS Nano, vol. 3, no. 2, pp. 279-290, 2009.

[34] R. A. Khaydarov, R. R. Khaydarov, R. L. Olsen, and S. E. Rogers, "Water disinfection using electrolytically generated silver, copper and gold ions," Journal of Water Supply: Research and Technology-AQUA, vol. 53, no. 8, pp. 567-572, 2004.

[35] R. A. Khaydarov, R. R. Khaydarov, O. Gapurova, Y. Estrin, and T. Scheper, "Electrochemical method for the synthesis of silver nanoparticles," Journal of Nanoparticle Research, vol. 11, no. 5, pp. 1193-1200, 2009.

[36] D. De Soete, R. Gijbels, and J. Hoste, Neutron Activation Analysis, 1972.

[37] T. Mosmann, "Rapid colorimetric assay for cellular growth and survival: application to proliferation and cytotoxicity assays,"
Journal of Immunological Methods, vol. 65, no. 1-2, pp. 55-63, 1983.

[38] A. Haase, A. Mantion, P. Graf et al., "A novel type of silver nanoparticles and their advantages in toxicity testing in cell culture systems," Archives of Toxicology, vol. 86, no. 7, pp. 10891098, 2012.

[39] T. Meißner, A. Potthoff, and V. Richter, "Suspension characterization as important key for toxicological investigations," Journal of Physics: Conference Series, vol. 170, no. 1, Article ID 012012, 2009.

[40] S. Deguchi, T. Yamazaki, S.-A. Mukai, R. Usami, and K. Horikoshi, "Stabilization of C-60 nanoparticles by protein adsorption and its implications for toxicity studies," Chemical Research in Toxicology, vol. 20, no. 6, pp. 854-858, 2007.

[41] L. Siller, M.-L. Lemloh, S. Piticharoenphun et al., "Silver nanoparticle toxicity in sea urchin Paracentrotus lividus," Environmental Pollution, vol. 178, pp. 498-502, 2013. 

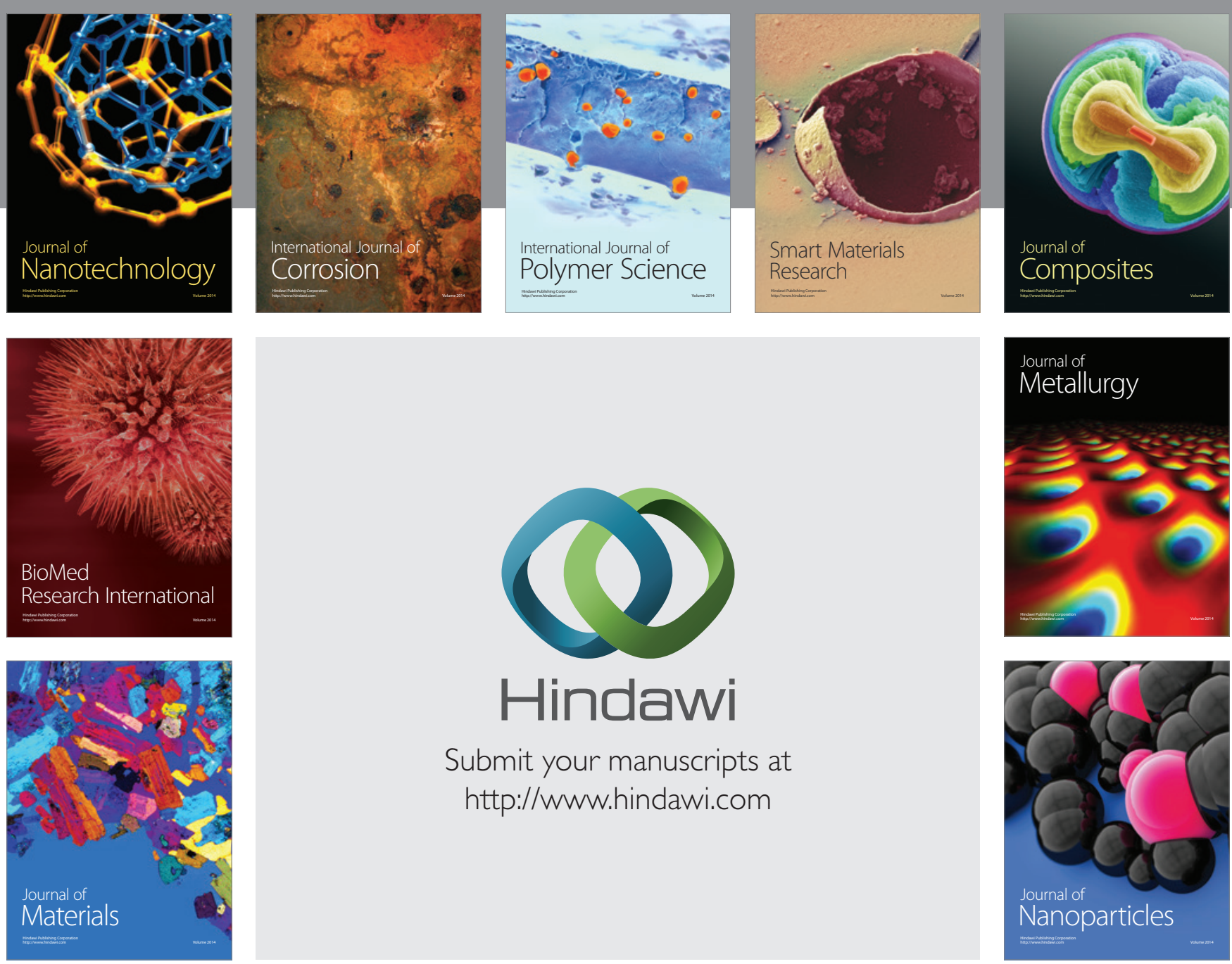

Submit your manuscripts at http://www.hindawi.com
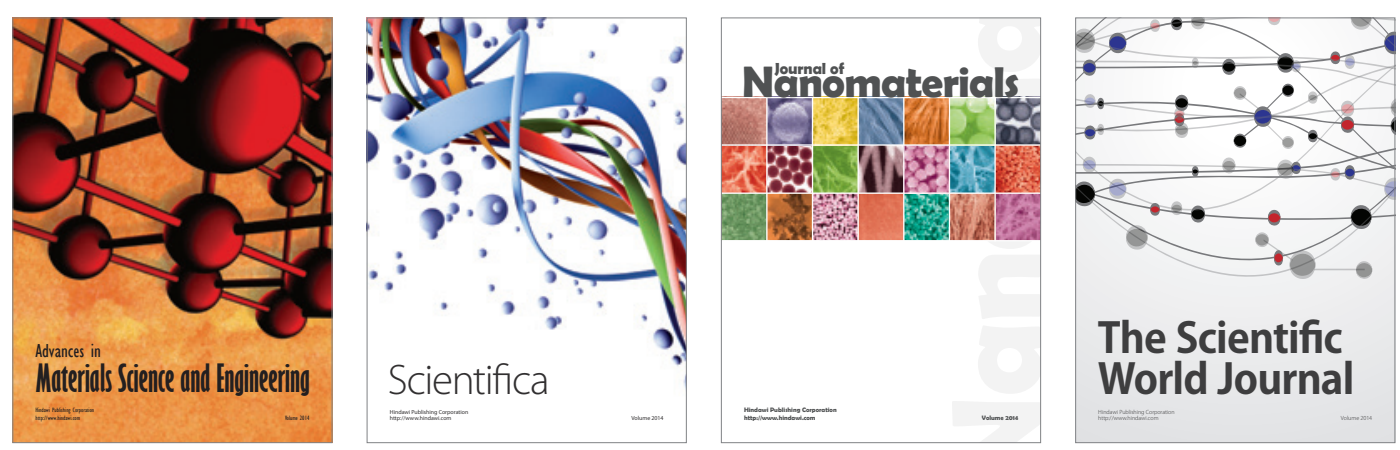

\section{The Scientific World Journal}
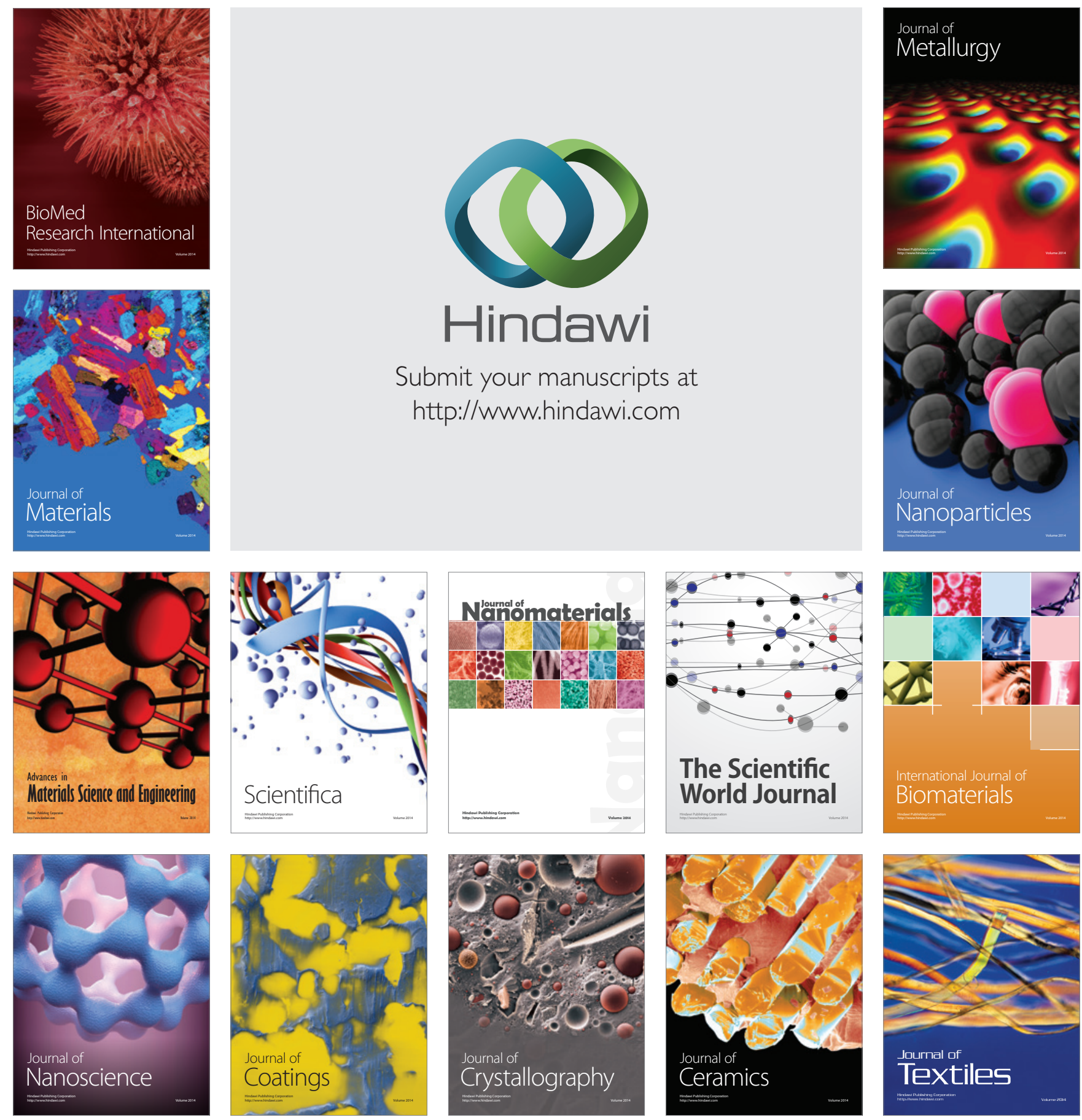